\title{
PETROGRAPHY AND GEOCHEMISTRY OF THE TOPAZ-BEARING GRANITE STOCKS IN ARTJÄRVI AND SÄÄSKJÄRVI, WESTERN MARGIN OF THE WIBORG RAPAKIVI GRANITE BATHOLITH
}

\author{
SARI LUKKARI
}

LUKKARI, SARI 2002. Petrography and geochemistry of the topaz-bearing granite stocks in Artjärvi and Sääskjärvi, western margin of the Wiborg rapakivi granite batholith. Bulletin of the Geological Society of Finland 74, Parts 1-2, 115 132.

The Artjärvi and Sääskjärvi granite stocks at the western margin of the Wiborg rapakivi batholith are multiphase rapakivi granite intrusions in which the most evolved phase is topaz-bearing granite. The Artjärvi stock is composed of porphyritic and even-grained biotite granite and even-grained topaz granite, and the Sääskjärvi stock comprises even-grained biotite granite and porphyritic topaz granite. The granites are metaluminous to peraluminous A-type granites, showing within-plate (WPG) geochemical characteristics. The topaz granites from the Artjärvi and Sääskjärvi stocks are petrographically and geochemically similar to other topaz-bearing rapakivi granites in Finland. The anomalous geochemistry of the topaz granite is essentially magmatic; postmagmatic reactions have only slightly modified its composition. Greisen veins, some of which are mineralized, are widely found associated with the Artjärvi and Sääskjärvi stocks.

The most characteristic feature of the Artjärvi granite stock is a stockscheider at the roof contact of the topaz granite. The stockscheider is composed of schlieren layering and pegmatite layers parallel to the contact. The most probable mechanism for the formation of the schlieren layering is velocity-gradient sorting parallel to the flow, which led to accumulation of mafic minerals along the upper contact of the topaz granite. Cooling and contraction of the topaz granite formed fractures parallel to the roof contact and the residual pegmatite magmas were injected along the fractures forming pegmatite layers. Textures like graphic intergrowths, aplitic groundmass and fan-shaped alkali feldspar crystals associated with the Artjärvi porphyritic biotite granite and pegmatite indicate crystallization from undercooled magma. Miarolitic cavities found in the porphyritic biotite granite and topaz granite indicate at least local volatile saturation.

Key words: granites, rapakivi, topaz, stocks, geochemistry, pegmatite, stockscheider, schlieren, greisen, Proterozoic, Artjärvi, Sääskjärvi, Finland

Sari Lukkari: Department of Geology, P.O. Box 64, FIN-00014 University of Helsinki, Finland 


\section{INTRODUCTION}

Topaz-bearing granites are known as potential hosts for tin and tungsten mineralization. Several important Sn polymetallic deposits in Brazil and Russian Karelia, and $\mathrm{Fe}-\mathrm{Cu}$ and $\mathrm{Cu}-\mathrm{U}-\mathrm{Au}-\mathrm{Ag}$ deposits in Missouri and South Australia are known to be associated with geochemically specialized topaz-bearing granites genetically related to rapa- kivi granites (Haapala 1995). In Finland, topazbearing late-stage members of the rapakivi granite association have been described from the Eurajoki stock (Haapala 1977a, 1997), Kymi stock (Haapala \& Ojanperä 1972, Haapala 1988), Suomenniemi batholith (Rämö 1991), and Ahvenisto complex (Edén 1991). This paper describes mode of occurrence, petrography, chemistry, and
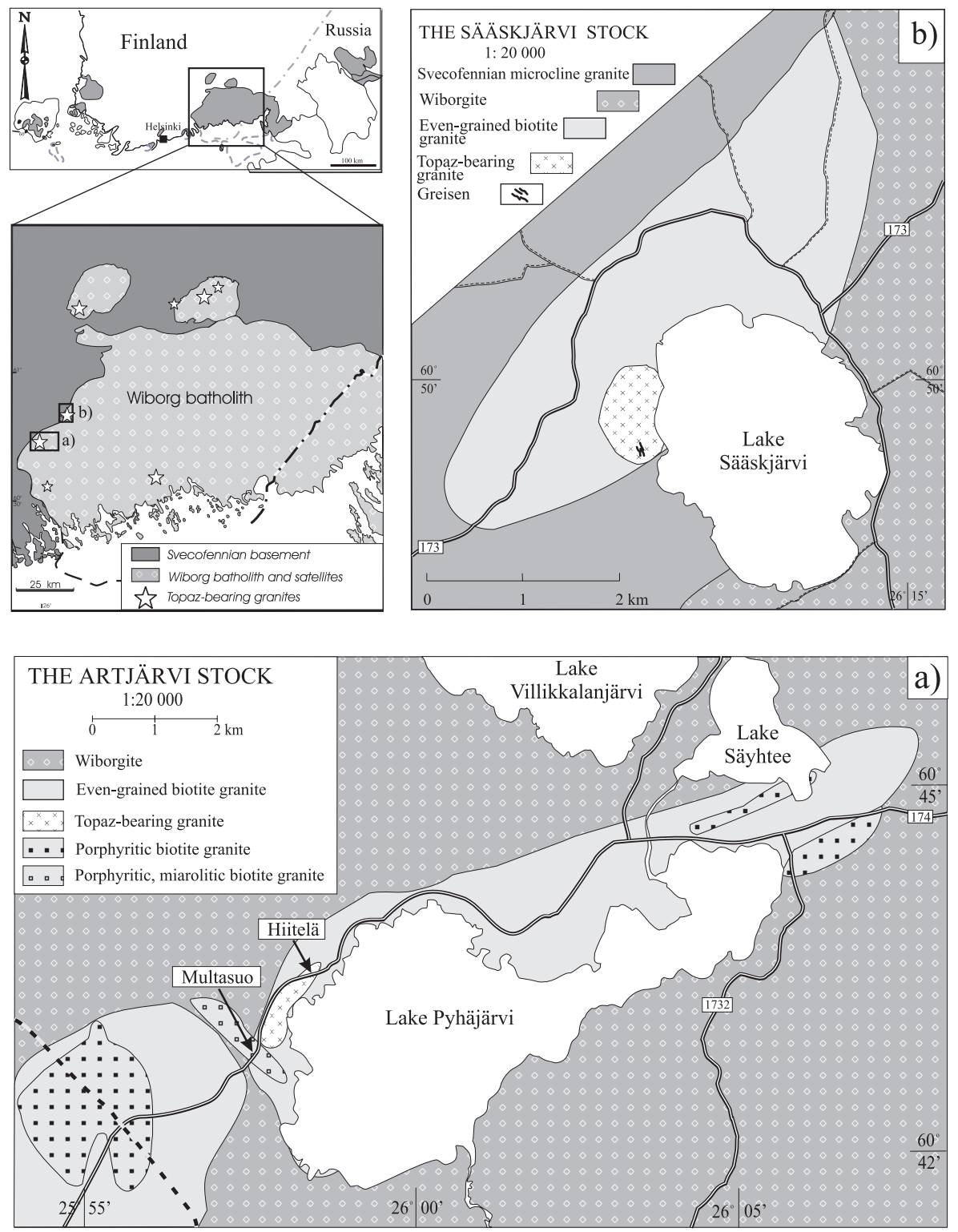

Fig. 1. Map showing the localities of the topaz-bearing granite stocks in the Wiborg rapakivi granite batholith and its satellites, and lithologic maps from a) the Artjärvi granite stock and b) the Sääskjärvi granite stock. 
contact phenomena of the Artjärvi and Sääskjärvi topaz granite stocks from the Wiborg batholith, compares their geochemistry with other topaz granite stocks in Finland, and discusses the greisen-type mineralization associated with these topaz granites.

\section{GEOLOGICAL SETTING}

The $1.64 \mathrm{Ga}$ Wiborg rapakivi batholith of SE Finland is one of four large rapakivi batholiths in Finland. It consists of several different granite varieties ranging from subsolvus hornblende granites to leucocratic topaz-bearing microcline-albite granites, and small bodies of contemporaneous mafic rocks (Rämö \& Haapala 1995). The latest intrusive phases in the batholith are topaz-bearing granites, which represent the most evolved melt fractions of rapakivi systems. The topaz granites occur as small stocks intruding the earlier rapakivi granites. The known topaz granite stocks within the Wiborg rapakivi granite area are shown in Fig. 1. The Artjärvi and Sääskjärvi granite stocks crop out at the western margin of the Wiborg batholith.

\section{GEOLOGY AND PETROGRAPHY}

\section{Artjärvi granite stock}

The Artjärvi granite stock is an ellipsoidal pluton (4 by $16 \mathrm{~km}$ ) located $80 \mathrm{~km}$ northeast of Helsinki. It contains three main phases: porphyritic biotite granite, even-grained biotite granite, and even-grained topaz granite (Fig. 1a). The evengrained biotite granite composes the main part of the stock,encloses smaller masses of porphyritic biotite granite and is cut by topaz granite. The porphyritic biotite granite and topaz granite phases have at their upper contacts marginal stockscheiders defined by biotite-rich and pegmatitic layers parallel to the contact. In terms of modal composition most of the samples are syenogranites; only two porphyritic biotite granite samples plot in the monzogranite field (Fig. 2).

\section{Porphyritic biotite granite}

The porphyritic biotite granite consists of euhedral to subhedral alkali feldspar and plagioclase megacrysts with fine-grained aplitic groundmass. Alkali feldspar megacrysts measure as much as 4 $\mathrm{cm}$ and plagioclase megacrysts as much as $2 \mathrm{~cm}$

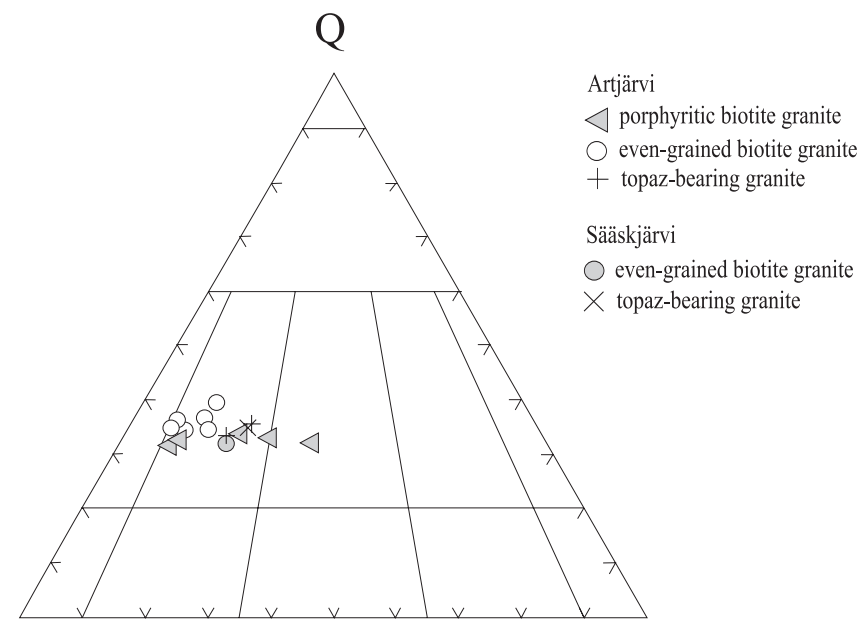

A

Fig. 2. Representative modal compositions of granites from the Artjärvi and Sääskjärvi granite stocks plotted in the IUGS modal classification diagram (Le Maitre et al. 1989). Modal compositions are based on point-counting analyses (1500 points from each sample) and manual area-counting analyses from cut and stained samples (area of 40 by $40 \mathrm{~mm}$ ). The staining method is described by Elliott (1999 and references therein). The area-counting method was used for coarse-grained and porphyritic samples $17 \mathrm{~F}, 21 \mathrm{~B}, 55 \mathrm{~A}, 59$ and 103 (Table 1). 
in length. The size and abundance of the megacrysts vary from place to place. Alkali feldspar is typically strongly red-pigmented string perthite and is rarely mantled by plagioclase. The core of plagioclase is strongly altered to sericite and locally to muscovite, epidote, and calcite. The groundmass consists of euhedral, rounded crystals of early quartz ("drop" quartz), euhedral to subhedral plagioclase, subhedral alkali feldspar, and late interstitial quartz. In addition to biotite, accessory minerals include zircon, apatite, fluorite, and ilmenite. Biotite, apatite, zircon, and ilmenite commonly form clots which vary in size from 1 to $5 \mathrm{~mm}$. These mafic clots may have formed when the early-crystallized phases clustered to minimize their surface energy (Wall et al. 1987).

Adjacent to the contact against the earlier rapakivi granite wiborgite, the porphyritic biotite granite contains abundant miarolitic cavities, pegmatite pockets, and distinct aplitic groundmass having granophyric texture. These textural features are typically associated with high-level granitic intrusions and, in the case of miarolitic cavities, involve separation of a fluid phase. The finegrained aplitic nature can be related to loss of the fluid (undercooling). Miarolitic cavities vary from 0.5 to $2.0 \mathrm{~cm}$ in diameter and are usually filled by quartz, plagioclase, alkali feldspar, fluorite, as well as secondary epidote, chlorite, and kaolinite. Pegmatite pockets are irregular in shape and vary in size from a few centimeters to tens of centimeters. The pockets consist mainly of quartz and alkali feldspar megacrysts; plagioclase, biotite, fluorite, and secondary chlorite occur as common accessory minerals.

\section{Even-grained biotite granite}

The even-grained biotite granite has sharp contacts against its country rocks wiborgite and porphyritic biotite granite. The presence of porphyritic biotite granite inclusions within the even-grained biotite granite suggests earlier emplacement of the porphyritic phase. The even-grained biotite granite is homogeneous, fine- to medium-grained rock, composed of alkali feldspar, plagioclase and quartz. Biotite is the only mafic silicate. Quartz occurs mainly as euhedral drop quartz but late interstitial quartz is also present. Alkali feldspar and plagioclase grains range from 2 to $6 \mathrm{~mm}$ and drop quartz from 1 to $2 \mathrm{~mm}$ in diameter. Alkali feldspar occurs as subhedral to anhedral string perthite grains, which are locally mantled by plagioclase. The cores of plagioclase grains are strongly sericitized and locally altered to epidote. Accessory minerals include fluorite, zircon, apatite, anatase, and ilmenite.

\section{Topaz-bearing granite}

The topaz-bearing granite occurs as a small elongated intrusive body sharply cutting the evengrained biotite granite. It is a homogeneous, finegrained granite with average grain size from 0.5 to $2 \mathrm{~mm}$. It is composed of subhedral to anhedral alkali feldspar, euhedral to subhedral plagioclase, and quartz. Alkali feldspar occurs as vein and coarse string perthite and is never mantled by plagioclase. Plagioclase is altered to sericite, muscovite, fluorite, and locally to topaz. Quartz occurs mainly as euhedral drop quartz but anhedral latecrystallized quartz is also present. In addition to biotite, accessory minerals include topaz, fluorite, zircon, apatite, monazite, molybdenite, uraninite, anatase, and ilmenite. Primary topaz occurs as small subhedral grains showing crystal faces against alkali feldspar, and as acicular inclusions in the late quartz.

Evidence of postmagmatic alteration can be found in the topaz-bearing and even-grained biotite granite phases. Postmagmatic reactions involve exsolution and minor recrystallization of alkali feldspar, producing intergranular albite rims between adjacent alkali feldspar grains and between alkali feldspar and plagioclase grains (see Haapala 1997). Subsolidus alteration of biotite to chlorite, and of plagioclase to topaz, fluorite, and muscovite indicate that the postmagmatic fluids have caused chemical changes in the granite.

\section{Stockscheider}

Marginal layered pegmatite-bearing zones, stockscheiders, associated with the roof contacts of the 


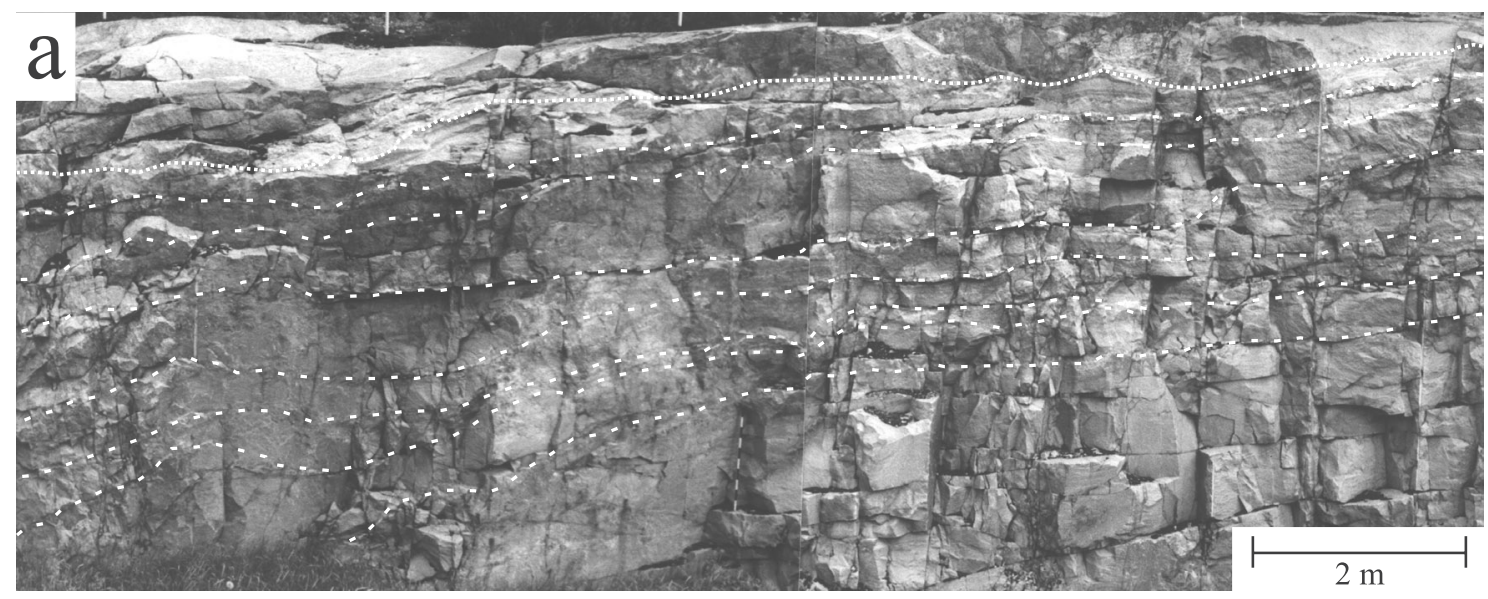

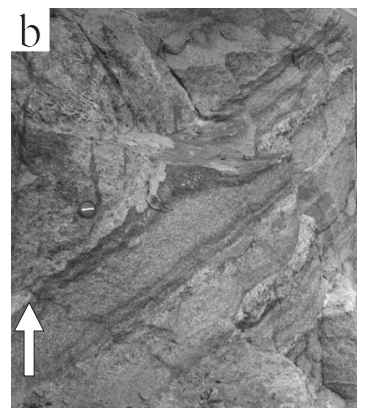
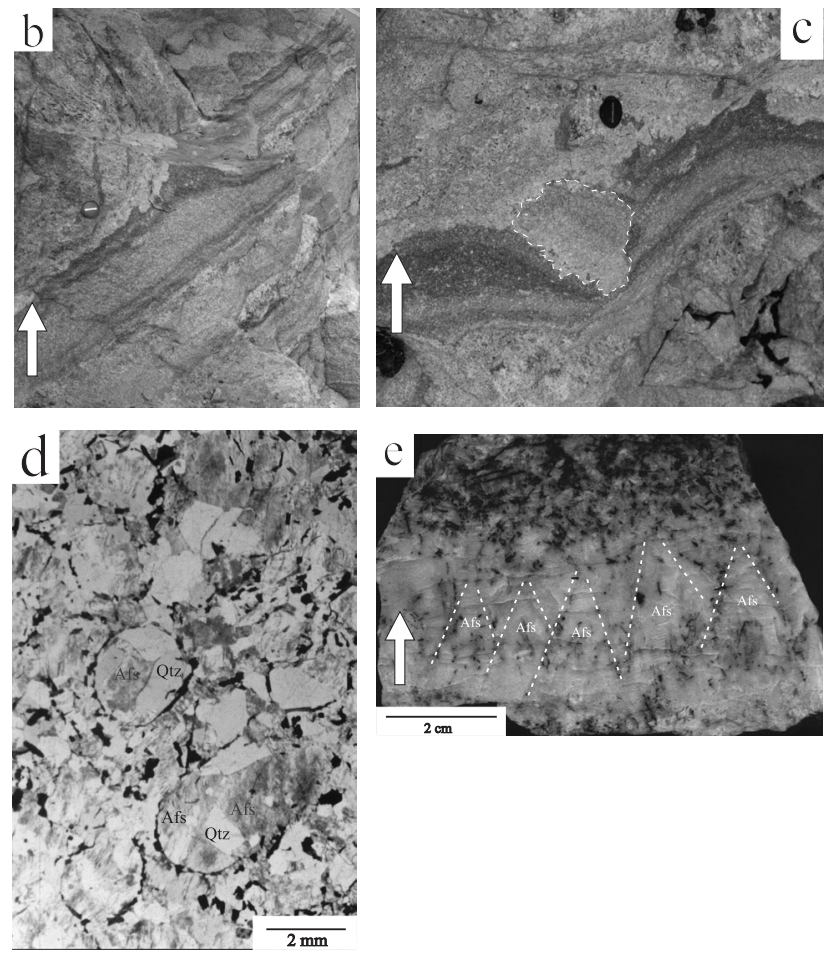

topaz granite and porphyritic biotite granite, are found in two road cuts, labelled Hiitelä and Multasuo in Fig. 1a. At Hiitelä the contact between the topaz granite and even-grained biotite granite is marked by a $3 \mathrm{~m}$ wide marginal stockscheider. The stockscheider consists essentially of finegrained topaz granite with numerous $\leq 15 \mathrm{~cm}$ thick pegmatite layers parallel to the contact (Fig. 3a). Furthermore, the upper part of the stockscheider, close to the contact, is characterized by parallel
Fig. 3. Structures from the Hiitelä marginal stockscheider at the roof contact of the topaz. granite from the Artjärvi granite stock. Diameter of the lens cap in b) and c) is $5 \mathrm{~cm}$. a) Photograph of the marginal stockscheider. The upper contact of the stockscheider is marked with a white dotted line. The pegmatite layers are marked with white dashed lines. b) Dark biotiterich layers showing undulate contact against the overlaying even-grained biotite granite. White arrow shows the contact. c) Part of crystallized margin (marked with white dotted line) has collapsed into the biotite-rich melt. White arrow shows the contact. d) Photomicrograph (planepolarized light) showing biotite spherules surrounding rounded alkali feldspar (Afs) and quartz (Qtz) aggregates. e) Photograph of fanshaped alkali feldspars (Afs) in pegmatite layer. White dotted lines mark the crystal boundaries of alkali feldspars. White arrow points towards the hanging wall contact. fine-scale layering showing a sharp but undulate contact against the overlaying even-grained biotite granite (Fig. 3b). In places the fine-scale layering is distorted by fragments of early-crystallized marginal granite (Fig. 3c).

In detail, the dark layers show grading in the proportions of mafic silicates. Generally the layers have sharp bases and transitional upper parts, but in the uppermost layer the amount of the mafic minerals decreases downwards from the upper 


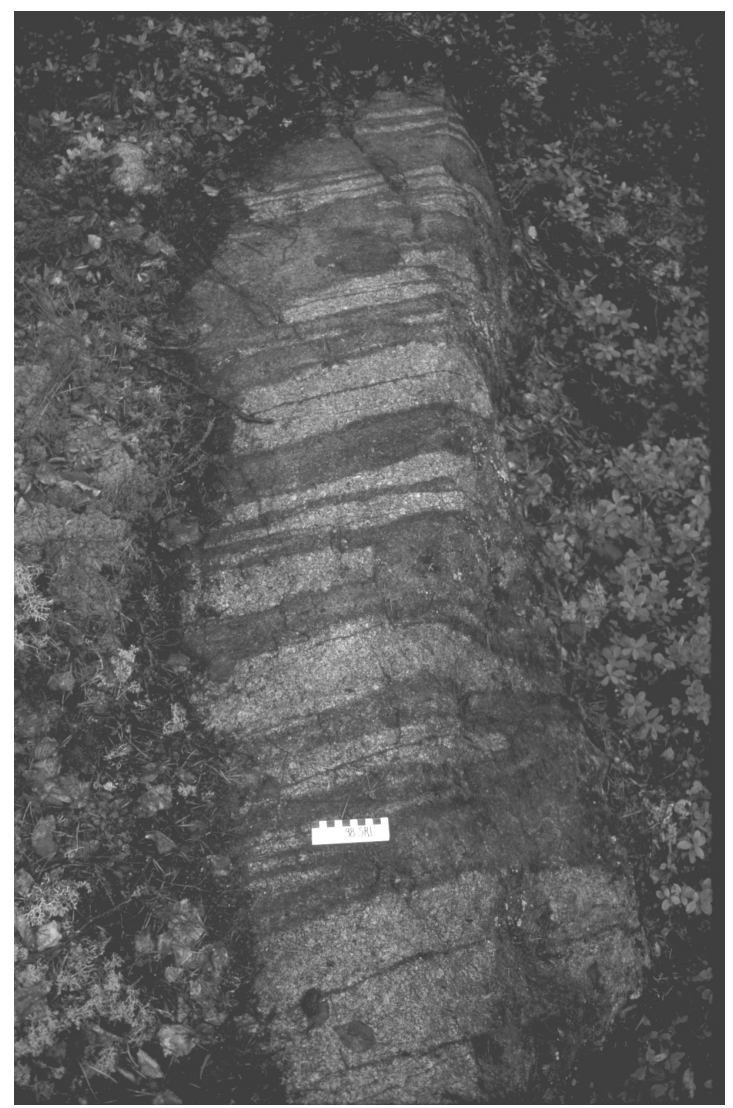

Fig. 4. Greisen veins in topaz granite at Sääskjärvi. Length of the scale is $10 \mathrm{~cm}$.

contact. The dark layers are enriched in biotite, plagioclase, zircon, and apatite compared to the host topaz granite. Biotite occurs as spheres (2-4 $\mathrm{mm}$ in diameter) surrounding aggregates of quartz and alkali feldspar grains (Fig. 3d) and as crystals aligned parallel to the layering. Euhedral plagioclase crystals occur as accumulations in the dark layers, with interstitial quartz and alkali feldspar.

The pegmatite layers cut the fine-scale layering as well as the topaz granite, and locally they bifurcate. They are homogeneous with no internal layering, but in a few layers fan-shaped alkali feldspar crystals show directional growing away from the upper contact (Fig. 3e). Besides alkali feldspar, the pegmatite layers contain quartz, plagioclase, and biotite as the main minerals, and topaz, zircon, fluorite, ilmenite, and apatite as ac- cessory minerals. The pegmatite layers have graphic quartz - alkali feldspar and quartz - plagioclase intergrowths.

At Multasuo the contact between the porphyritic biotite granite and wiborgite is marked by a $1 \mathrm{~m}$ wide stockscheider. This stockscheider is texturally similar to the stockscheider at the apical contact of the topaz granite. It consists mainly of medium- and coarse-grained equigranular biotite granite and thin pegmatite layers and pockets. The even-grained granite contains a few irregular biotite-rich layers. As distinct from the Hiitelä stockscheider at the margin of topaz granite, the Multasuo stockscheider shows sharp contacts against both wiborgite and porphyritic biotite granite, and it contains rounded inclusions of porphyritic biotite granite. These observations indicate that the latter stockscheider was emplaced as a later, dike-like body along the contact between the two granites.

\section{Sääskjärvi granite stock}

The Sääskjärvi granite stock ( 6 by $2 \mathrm{~km}$ ) crops out $20 \mathrm{~km}$ northeast of the Artjärvi granite stock at the margin of the Wiborg batholith and forms an outlier into the Svecofennian crust (Fig. 1b). The stock consists mainly of medium-grained equigranular biotite granite, which encloses a rounded $0.5 \mathrm{~km}^{2}$ body of porphyritic topaz granite. The even-grained biotite granite shows sharp contacts against both wiborgite and Svecofennian microcline granite but the contact against topaz granite is not exposed. Modal compositions of the biotite granite and topaz granite are syenogranites (Fig. 2).

\section{Even-grained biotite granite}

The even-grained biotite granite is homogeneous, medium-grained granite with average grain size from 1 to $3 \mathrm{~mm}$. It is composed of alkali feldspar, plagioclase, and quartz. Minor constituents besides biotite include fluorite, zircon, ilmenite, anatase, and apatite. Alkali feldspar is subhedral to anhedral string perthite, rarely mantled by plagioclase. Plagioclase occurs as euhedral to subhedral grains, which are commonly strongly altered to 


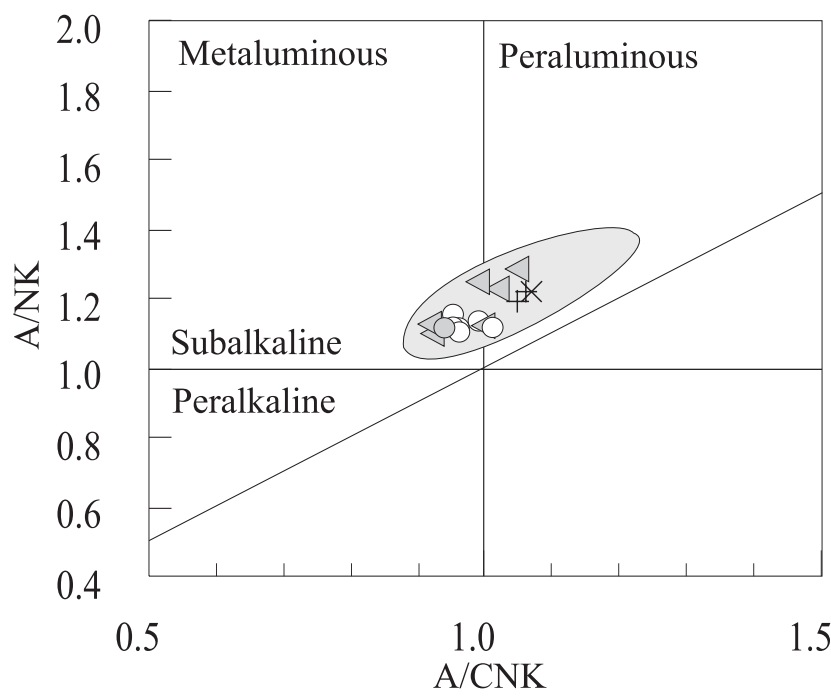

\section{ARTJÄRVI \\ $\triangle$ porphyritic biotite granite \\ $\bigcirc$ even-grained biotite granite \\ + topaz-bearing granite \\ SÄÄSKJÄRVI \\ even-grained biotite granite \\ $X$ topaz-bearing granite}

Topaz-bearing granites

from other localities in Finland

Fig. 5. Artjärvi and Sääskjärvi granites plotted in an $\mathrm{A} / \mathrm{NK}$ (molecular $\mathrm{Al}_{2} \mathrm{O}_{3} /\left(\mathrm{Na}_{2} \mathrm{O}+\mathrm{K}_{2} \mathrm{O}\right)$ ) vs. A/CNK (molecular $\left.\mathrm{Al}_{2} \mathrm{O}_{3} /\left(\mathrm{CaO}+\mathrm{Na}_{2} \mathrm{O}+\mathrm{K}_{2} \mathrm{O}\right)\right)$ variation diagram showing the subalkaline and metaluminous or peraluminous character of the granites. The data that were used to construct the Finnish topaz granite field are from Eurajoki (Haapala 1977, 1997), Suomenniemi (Rämö 1991), Ahvenisto (mean of 26 analyses) (Edén 1991), Kymi (Haapala 1988), and Kymi, Liljendal, Eurajoki and Suomenniemi topaz granites (unpublished data by the author).

sericite, muscovite and epidote. Intergranular albite rims are common between adjacent alkali feldspar grains and between alkali feldspar and plagioclase grains. Quartz occurs as euhedral drop quartz and interstitial anhedral quartz. Topaz is not found in this granite type.

\section{Topaz-bearing granite}

The topaz granite is slightly porphyritic with euhedral alkali feldspar megacrysts in a mediumgrained groundmass. Alkali feldspar megacrysts measure up to $1 \mathrm{~cm}$ in diameter and locally show weak orientation. The abundance and size of the megacrysts vary, and in places the granite is nearly equigranular. The groundmass is composed of alkali feldspar, plagioclase and quartz. Accessory minerals include topaz, fluorite, zircon, anatase, ilmenite, and apatite. Alkali feldspar occurs as subhedral and anhedral string perthite and is strongly pigmented (Fe-oxide?). Euhedral and subhedral plagioclase is partly altered to sericite, muscovite, topaz, and fluorite. Quartz occurs as euhedral drop quartz as well as interstitial late quartz. Topaz oc- curs as magmatic subhedral crystals having crystal faces against alkali feldspar and as an alteration product of plagioclase. Biotite occurs as the only mafic silicate and is partly chloritized.

Both granite phases from the Sääskjärvi stock have been modified by subsolidus reactions, including exsolution of alkali feldspar, recrystallization, and alteration of plagioclase and biotite.

\section{Greisen}

Greisen occurs as thin veins cutting the granites of the Artjärvi and Sääskjärvi stocks, as well as the surrounding older rapakivi granites. The width of the greisen veins ranges from $2 \mathrm{~cm}$ to more than $20 \mathrm{~cm}$, and in some cases they form vein swarms (Fig. 4). The orientation of the greisen veins varies from place to place and at a single outcrop several vein directions can be found. Greisen veins are mainly composed of quartz, muscovite, chlorite, fluorite, and topaz, and some mineralized veins contain sulfide minerals, cassiterite, and columbite. 

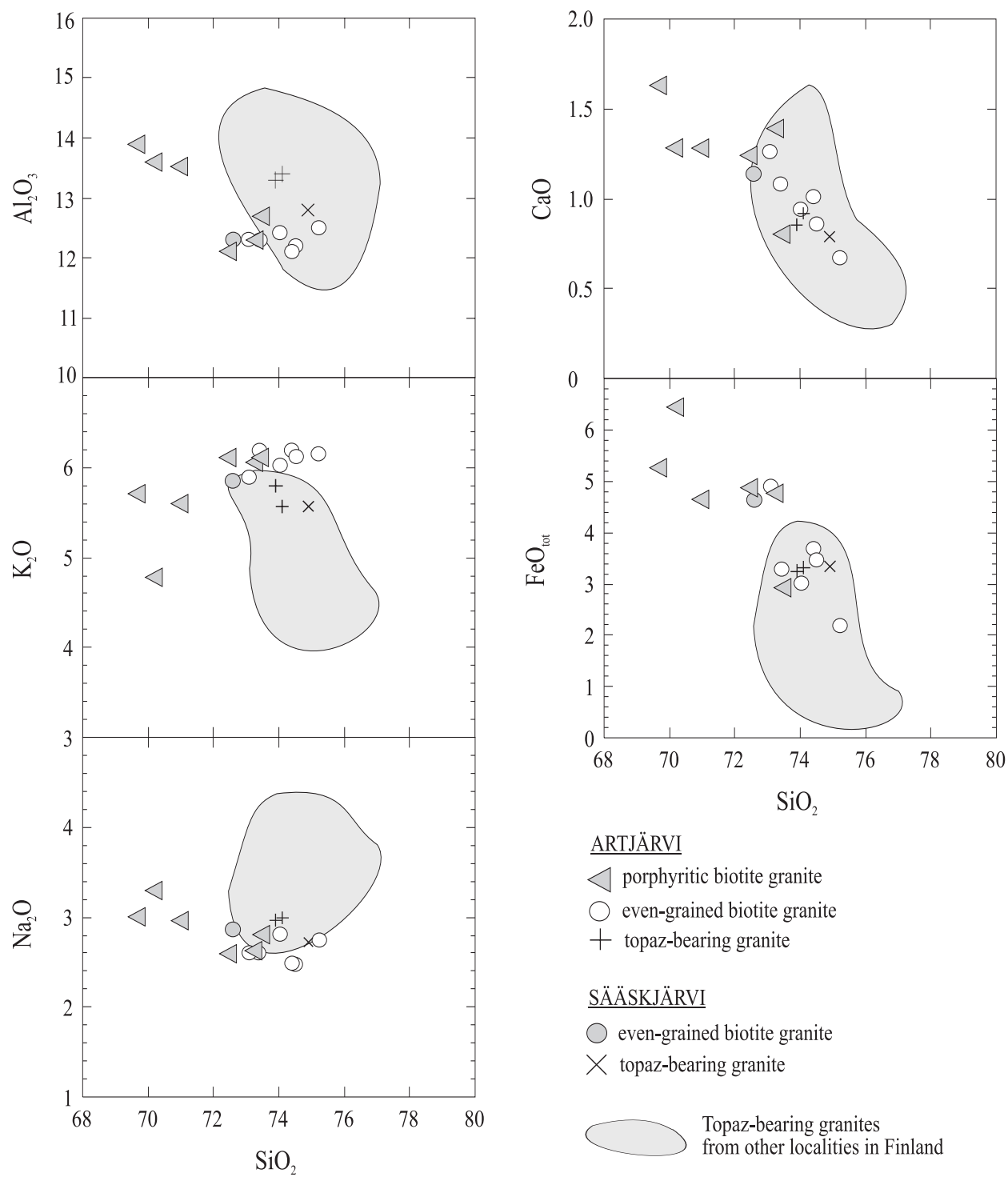

\section{$\underline{\text { ARTJÄRVI }}$}

$\triangle$ porphyritic biotite granite

$\bigcirc$ even-grained biotite granite

+ topaz-bearing granite

\section{$\underline{\text { SÄÄSKJÄRVI }}$}

$\bigcirc$ even-grained biotite granite

$X$ topaz-bearing granite

Topaz-bearing granites

from other localities in Finland

Fig. 6. Major element analyses (wt\%) of the Artjärvi and Sääskjärvi granites plotted in selected Harker diagrams. $\mathrm{FeO}$ tot denotes total iron as $\mathrm{FeO}$. Data sources for the Finnish topaz granite field as in Fig. 5.

\section{GEOCHEMISTRY}

\section{Major and trace elements}

The major and trace element compositions of the Artjärvi and Sääskjärvi granite stocks are given in Table 1 and shown in Figs. 5-7. For comparison, the composition range of topaz-bearing granites from other localities in Finland is shown as a dashed field in the diagrams.
The major element contents of the granites of the stocks show only restricted variation, because all the granites crystallized from highly evolved magmas. The porphyritic and even-grained biotite granites are metaluminous to weakly peraluminous, having A/CNK from 0.92 to 1.05 , the topazbearing granites are peraluminous with $\mathrm{A} / \mathrm{CNK}$ of 1.05 to 1.07 , and all phases are subalkaline with 
a)

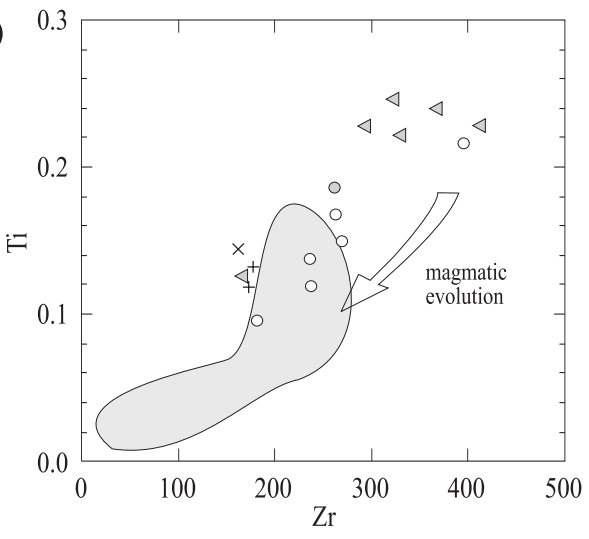

c)

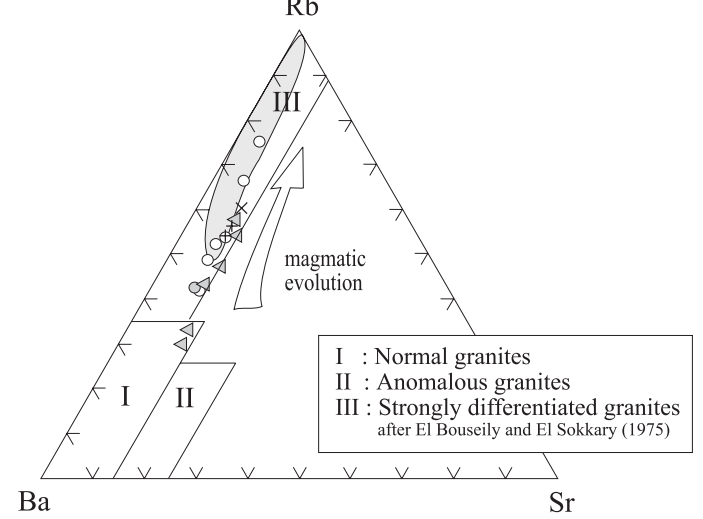

b)

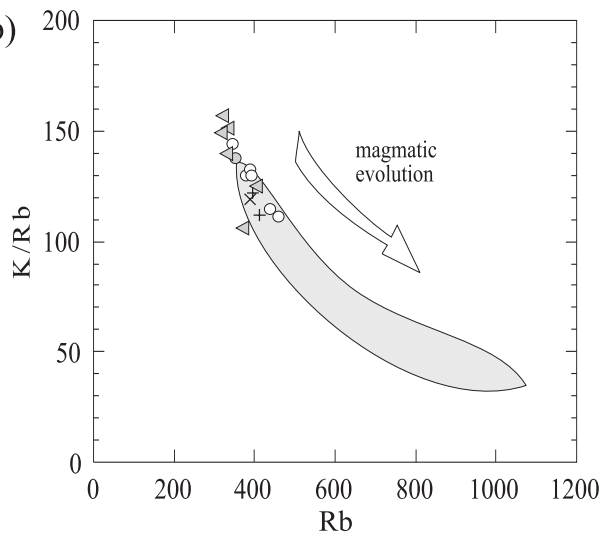

Artjärvi

$\triangleleft$ porphyritic biotite granite

$\bigcirc$ even-grained biotite granite

+ topaz-bearing granite

Sääskjärvi

$\bigcirc$ even-grained biotite granite

$X$ topaz-bearing granite

Topaz-bearing granites

from other localities in Finland

Fig. 7. Diagrams showing magmatic evolution of the granites from the Artjärvi and Sääskjärvi granite stocks. a) Ti vs. Zr, b) K/Rb vs. Rb, and c) Rb-Ba-Sr (after El Bouseily \& El Sokkary 1975) plots. Ti in wt\%, Zr, Rb, Ba and $\mathrm{Sr}$ in $\mathrm{ppm}$.

NK/A of 0.78 to 0.90 (Table 1 and Fig. 5). Variation diagrams (Figs. 6 and $7 \mathrm{a}$ ) show that the older porphyritic biotite granite has slightly higher concentration of $\mathrm{FeO}_{\text {tot }}, \mathrm{CaO}, \mathrm{TiO}_{2}$ and $\mathrm{Zr}$, and lower content of $\mathrm{SiO}_{2}$ and $\mathrm{K}_{2} \mathrm{O}$ than the even-grained biotite granite and topaz granite. The porphyritic biotite granite plots mainly outside the reference field whereas the topaz granites invariably plot within the same field as the other topaz granites of Finland. The main chemical characteristics of the topaz granites are their high concentrations of $\mathrm{SiO}_{2}(>73.9 \mathrm{wt} \%)$, elevated contents of $\mathrm{F}(0.25$ $0.31 \mathrm{wt} \%), \mathrm{Li}(62-85 \mathrm{ppm})$ and $\mathrm{Rb}(389-412 \mathrm{ppm})$, and low contents of $\mathrm{MgO}(<0.26 \mathrm{wt} \%), \mathrm{TiO}_{2}$ (<0.24 wt\%), Ba (200-282 ppm), Sr (56-65 ppm) and $\mathrm{Zr}$ (162-177 ppm); these characteristics are typical for geochemically specialized tin granites
(Tischendorf 1977). However, it should be noted that the granites of this study do not reach the very high levels of $\mathrm{Sn}, \mathrm{Rb}, \mathrm{F}$, and $\mathrm{Li}$ recorded for the true tin granites.

The magmatic evolution of the granites of the Artjärvi and Sääskjärvi stocks is shown in Figs. 7a-7c. The Ti vs. $\mathrm{Zr}$ diagram shows a positive slope with decreasing contents from the porphyritic biotite granite through the even-grained biotite granite to the topaz granite (Fig. 7a). The K/ $\mathrm{Rb}$ vs. $\mathrm{Rb}$ diagram shows increasing $\mathrm{Rb}$ content from the porphyritic biotite granite to topaz granite (Fig. 7b). In the Rb-Ba-Sr diagram (Fig. 7c), most of the samples plot in the strongly differentiated granite field; only two porphyritic biotite granite samples plot in the normal granite field. The $\mathrm{Rb}-$ $\mathrm{Ba}-\mathrm{Sr}$ differentiation trend shows $\mathrm{Rb}$ enrichment 


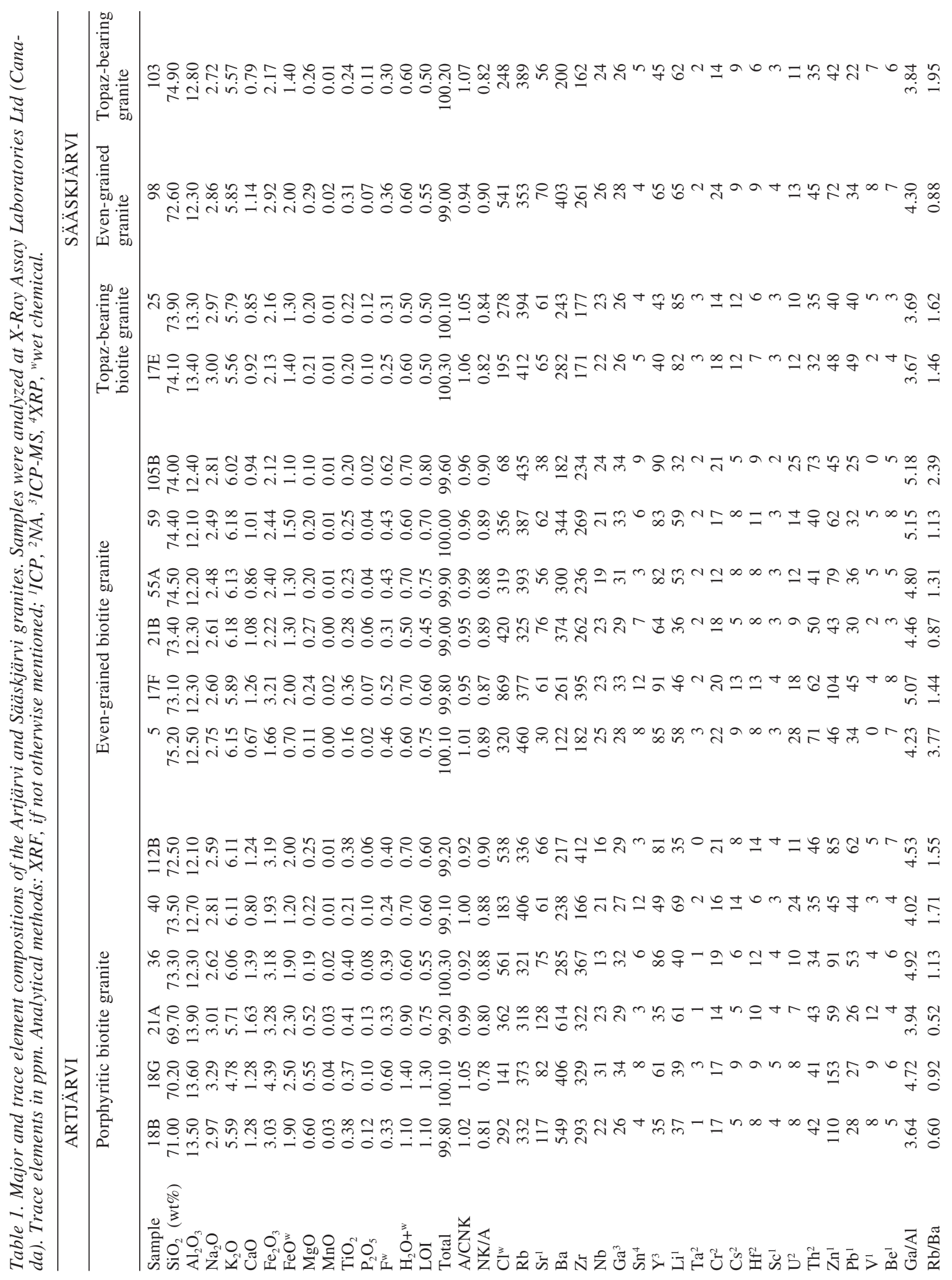


Table 2. Average major and trace element compositions of the Artjärvi stockscheider. The samples were analyzed at the Geochemical Laboratory of the Department of Geology, University of Helsinki. Trace elements in ppm. Analytical method: ICP-AES, L.O.I. as weight loss after ignition at $1000^{\circ} \mathrm{C}$.

\section{HIITELÄ MARGINAL STOCKSCHEIDER}

\begin{tabular}{|c|c|c|c|c|c|c|c|c|}
\hline & \multicolumn{2}{|c|}{ Granitic layers } & \multicolumn{3}{|c|}{ Schlieren layers } & \multicolumn{3}{|c|}{ Pegmatite bands } \\
\hline $\mathrm{n}$ & & 5 & & 3 & & & 5 & \\
\hline $\mathrm{SiO}_{2}$ & 75.50 & \pm 0.94 & 70.67 & \pm & 0.58 & 75.84 & \pm & 4.11 \\
\hline $\mathrm{Al}_{2} \mathrm{O}_{3}$ & 13.09 & \pm 0.68 & 11.65 & \pm & 1.88 & 13.01 & \pm & 3.07 \\
\hline $\mathrm{Na}_{2} \mathrm{O}$ & 2.90 & \pm 0.31 & 2.23 & \pm & 0.21 & 2.75 & \pm & 0.59 \\
\hline $\mathrm{K}_{2} \mathrm{O}$ & 5.40 & \pm 0.74 & 4.97 & \pm & 0.91 & 5.92 & \pm & 1.02 \\
\hline $\mathrm{CaO}$ & 0.78 & \pm 0.13 & 3.60 & \pm & 1.19 & 0.62 & \pm & 0.18 \\
\hline $\mathrm{Fe}_{2} \mathrm{O}_{3}^{\text {tot }}$ & 1.83 & \pm 0.51 & 4.30 & \pm & 1.33 & 1.26 & \pm & 0.70 \\
\hline $\mathrm{MgO}$ & 0.09 & \pm 0.07 & 0.07 & \pm & 0.01 & 0.04 & \pm & 0.02 \\
\hline $\mathrm{MnO}$ & 0.02 & \pm 0.01 & 0.04 & \pm & 0.02 & 0.01 & \pm & 0.00 \\
\hline $\mathrm{TiO}_{2}$ & 0.11 & \pm 0.06 & 0.96 & \pm & 0.17 & 0.06 & \pm & 0.02 \\
\hline $\mathrm{P}_{2} \mathrm{O}_{5}$ & 0.07 & \pm 0.03 & 0.28 & \pm & 0.11 & 0.02 & \pm & 0.01 \\
\hline L.O.I. & 0.50 & \pm 0.44 & 1.42 & \pm & 0.56 & 0.29 & \pm & 0.20 \\
\hline Total & 100.27 & \pm 0.32 & 100.17 & \pm & 0.73 & 99.83 & \pm & 0.50 \\
\hline \multicolumn{9}{|c|}{ Trace elements } \\
\hline $\mathrm{Ba}$ & 132 & \pm 115 & 220 & \pm & 55 & 55 & \pm & 24 \\
\hline $\mathrm{Li}$ & 65 & \pm 41 & 62 & \pm & 32 & 50 & \pm & 57 \\
\hline $\mathrm{Sr}$ & 25 & \pm 17 & 37 & \pm & 3 & 21 & \pm & 7 \\
\hline $\mathrm{Rb}$ & 432 & \pm 61 & 283 & \pm & 47 & 496 & \pm & 181 \\
\hline $\mathrm{Y}$ & 80 & \pm 35 & 128 & \pm & 37 & 92 & \pm & 75 \\
\hline $\mathrm{Zr}$ & 292 & \pm 181 & 1163 & \pm & 530 & 80 & \pm & 50 \\
\hline $\mathrm{Sc}$ & 3 & \pm 1 & 7 & \pm & 3 & 2 & \pm & 1 \\
\hline $\mathrm{La}$ & 94 & \pm 48 & 218 & \pm & 81 & 49 & \pm & 26 \\
\hline $\mathrm{Ce}$ & 229 & \pm 126 & 482 & \pm & 175 & 111 & \pm & 60 \\
\hline $\mathrm{Nd}$ & 82 & \pm 52 & 157 & \pm & 50 & 37 & \pm & 16 \\
\hline
\end{tabular}

accompanied by Ba depletion from the porphyritic biotite granite to topaz-bearing granite. Two evengrained biotite granite samples from Artjärvi show the most evolved character in this diagram, which probably results from an increased $\mathrm{Rb}$ content of the samples owing to postmagmatic reactions.

Average major and trace element compositions of the granite and pegmatite layers from the Artjärvi stockscheider are given in Table 2. Granite and pegmatite layers are similar in composition. Pegmatite layers show slight enrichment in $\mathrm{K}_{2} \mathrm{O}$ and $\mathrm{Rb}$ and depletion in $\mathrm{CaO}, \mathrm{Fe}_{2} \mathrm{O}_{3}{ }^{\text {tot }}, \mathrm{TiO}_{2}$, and $\mathrm{P}_{2} \mathrm{O}_{5}$ compared with granite layers, probably because of the enrichment of alkali feldspar and depletion of mafic accessory minerals like biotite a)

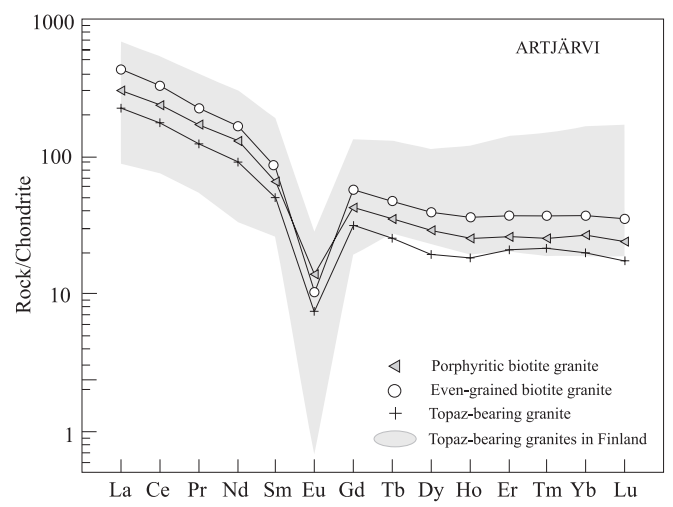

b)

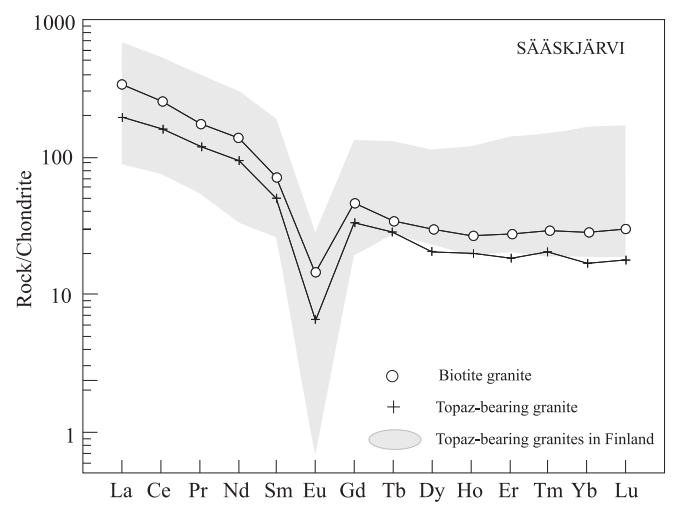

Fig. 8. Chondrite-normalized REE patterns of a) granites from Artjärvi and b) granites from Sääskjärvi. The plotted patterns are averages from the analyses listed in Table 3. Data for the Finnish topaz granite field as in Fig. 5. Normalizing values according to Boynton (1984).

and apatite. Biotite-rich layers in the upper part of the stockscheider clearly differ from the granite and pegmatite layers. They are enriched in $\mathrm{CaO}, \mathrm{Fe}_{2} \mathrm{O}_{3}$ tot $, \mathrm{TiO}_{2}, \mathrm{P}_{2} \mathrm{O}_{5}, \mathrm{Zr}, \mathrm{Ba}, \mathrm{La}, \mathrm{Ce}$, and $\mathrm{Nd}$, and slightly depleted in $\mathrm{Na}_{2} \mathrm{O}, \mathrm{K}_{2} \mathrm{O}$ and $\mathrm{SiO}_{2}$, owing to the abundance of plagioclase, biotite, zircon, and apatite. Whole rock compositions show that the principal chemical differences among the granite, pegmatite, and biotite-rich layers are controlled by mineral proportions.

\section{Rare earth elements}

REE abundances in the Artjärvi and Sääskjärvi granites are shown in Table 3 and their chondrite- 


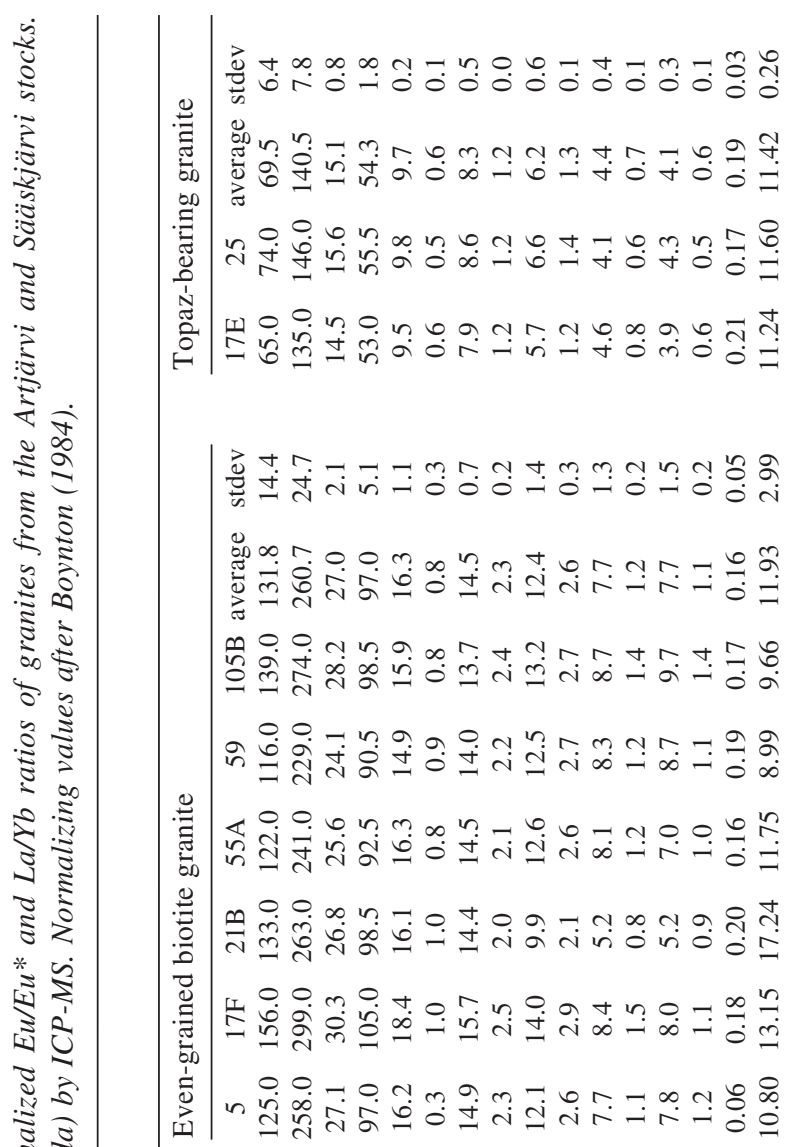

|

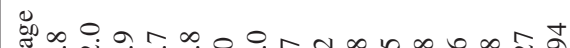
苛

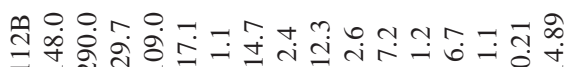

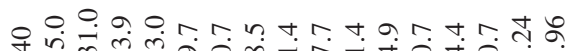

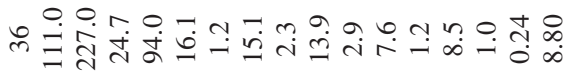

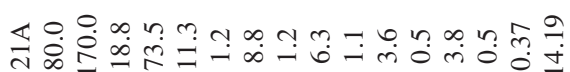

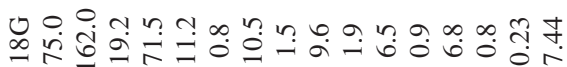
m n 
a)

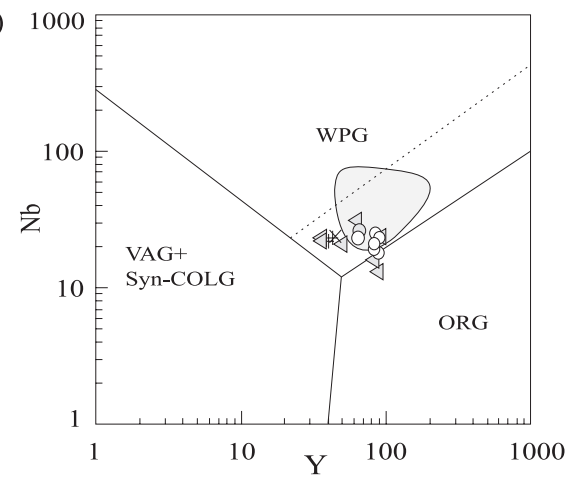

b)

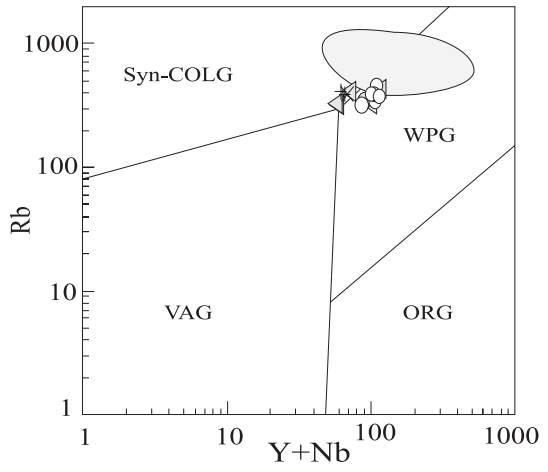

ARTJÄRVI

$\checkmark$ porphyritic biotite granite

$\bigcirc$ even-grained biotite granite

+ topaz-bearing granite

\section{$\underline{\text { SÄÄSKJÄRVI }}$}

$\bigcirc$ even-grained biotite granite

$X$ topaz-bearing granite

Topaz-bearing granites from other localities in Finland

Fig. 9. Analyses of the Artjärvi and Sääskjärvi granites plotted in a) $\mathrm{Nb} v \mathrm{vs} \mathrm{Y}$ and b) $\mathrm{Rb}$ vs. $\mathrm{Y}+\mathrm{Nb}$ tectonomagmatic discrimination diagrams of Pearce et al. (1984). Abbreviations denote ocean ridge granites (ORG), volcanic arc granites (VAG), within plate granites (WPG), and collision granites (COLG). In a) the dotted line shows the upper compositional boundary for ocean ridge granites from anomalous ridge segments. Data for the Finnish topaz granite field as in Fig. 5.

\section{ARTJÄRVI}

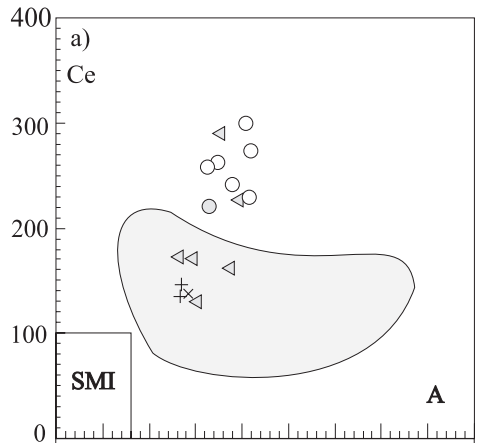

$\triangleleft$ porphyritic biotite granite

$\bigcirc$ even-grained biotite granite

+ topaz-bearing granite

\section{$\underline{\text { SÄÄSKJÄRVI }}$}

$\bigcirc$ even-grained biotite granite

$X$ topaz-bearing granite

Topaz-bearing granites from other localities in Finland
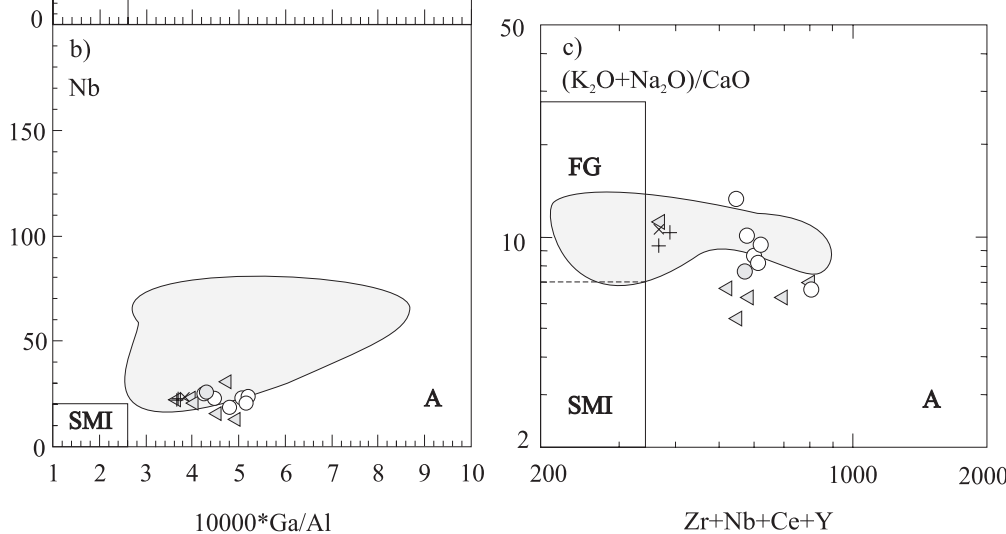

Fig. 10. Analyses of the Artjärvi and Sääskjärvi granites plotted in a) Ce vs. $10000 \mathrm{Ga} / \mathrm{Al}, \mathrm{b}) \mathrm{Nb}$ vs. $10000 * \mathrm{Ga} / \mathrm{Al}$, and c) $\left(\mathrm{K}_{2} \mathrm{O}+\right.$ $\left.\mathrm{Na}_{2} \mathrm{O}\right) / \mathrm{CaO}$ vs. $\mathrm{Zr}+\mathrm{Nb}+\mathrm{Ce}+\mathrm{Y}$ discrimination diagrams of Whalen et al. (1987). SMI for $S$-, $M$ and I-type granites, A for A-type granite, and $F G$ for fractionated granite. Data for the Finnish topaz granite field as in Fig. 5. 
normalized REE-patterns are plotted in Figs. 8a and $8 \mathrm{~b}$, respectively. The REE patterns of the granites from the Artjärvi stock are relatively enriched in light rare earth elements (LREE) [(La/ $\left.\mathrm{Yb})_{\mathrm{N}}=7.44-17.24\right]$ and have strong negative $\mathrm{Eu}$ anomalies $\left[\left(\mathrm{Eu} / \mathrm{Eu}^{*}\right)_{\mathrm{N}}=0.06-0.37\right]$. The porphyritic biotite granite has a less distinct negative $\mathrm{Eu}$ anomaly $\left[\left(\mathrm{Eu} / \mathrm{Eu}^{*}\right)_{\mathrm{N}}=0.21-0.37\right]$ than the topaz granite and even-grained biotite granite. The topaz granite is more depleted in REE than the evengrained and porphyritic biotite granites. The REE patterns of the even-grained biotite granite and topaz-bearing granite from the Sääskjärvi stock exhibit patterns similar to those of the granites from the Artjärvi stock $\left[(\mathrm{La} / \mathrm{Yb})_{\mathrm{N}} 11.85\right.$ and 11.75 , $\left(\mathrm{Eu} / \mathrm{Eu}^{*}\right)_{\mathrm{N}} 0.25$ and 0.16$]$. Enrichment of the LREE in relation to HREE is probably caused by fractionation of zircon (Rollinson 1993), and the negative Eu anomaly is due to feldspar fractionation. Europium partitions strongly into both feldspars during crystallization and thus the $\left(\mathrm{Eu} / \mathrm{Eu}^{*}\right)_{\mathrm{N}}$ decreases as differentiation progresses (Miller \& Mittlefehldt 1982). Typically, Finnish topaz granites have relatively flat REE pattern with lower LREE and higher HREE content and a deeper Eu anomaly than normal rapakivi granites (Haapala 1988), but the topaz granites from Artjärvi and Sääskjärvi are not as enriched in HREE and have REE patterns that are very similar to those of average rapakivi granites.

In the tectonomagmatic discrimination diagrams $\mathrm{Nb}$ vs. $\mathrm{Y}$ and $\mathrm{Rb}$ vs. $\mathrm{Y}+\mathrm{Nb}$ (Pearce et al. 1984), most of the granites plot in the field of within-plate granites (WPG), but some of the samples (e.g. topaz granites) plot in the $\mathrm{Rb} v \mathrm{vs} \mathrm{Y}+\mathrm{Nb}$ diagram in the syn-collisional granite field because of their high $\mathrm{Rb}$ content (Figs. 9a and 9b). In Figs 10a$10 \mathrm{c}$ the granites of Artjärvi and Sääskjärvi are plotted on Ce vs. $10000 * \mathrm{Ga} / \mathrm{Al}, \mathrm{Nb}$ vs. $10000 * \mathrm{Ga} /$ $\mathrm{Al}$ and $\left(\mathrm{K}_{2} \mathrm{O}+\mathrm{Na}_{2} \mathrm{O}\right) / \mathrm{CaO}$ vs. $\mathrm{Zr}+\mathrm{Nb}+\mathrm{Ce}+\mathrm{Y}$ discrimination diagrams of Whalen et al. (1987). All the samples plot exclusively in the A-type field because of their high Ga/Al $(10000 * \mathrm{Ga} / \mathrm{Al}=3$.65.2) and elevated $\mathrm{Nb}$ and $\mathrm{Ce}$ concentrations.

\section{DISCUSSION AND CONCLUSIONS}

\section{Petrology and geochemistry}

Petrographic and geochemical studies show that the Artjärvi and Sääskjärvi granite stocks are evolved multiphase rapakivi granite intrusions for which the order of emplacement was 1) porphyritic biotite granite, 2) even-grained biotite granite, and 3) topaz-bearing granite. Major and trace element chemistry shows that the general chemical evolution trends proceed from porphyritic biotite granite through even-grained biotite granite to topaz granite at Artjärvi and from even-grained biotite granite to topaz granite at Sääskjärvi. The topaz granites are depleted in $\mathrm{FeO}_{\text {tot }}, \mathrm{CaO}, \mathrm{TiO}_{2}$, $\mathrm{Zr}$, and $\mathrm{Ba}$, and enriched in $\mathrm{SiO}_{2}$ and $\mathrm{Rb}$ compared to the older porphyritic and even-grained biotite granites. All of the granites are A-type granites with a metaluminous to peraluminous composition, and show within plate (WPG) geochemical characteristics.

The topaz granites from Artjärvi and Sääskjärvi show petrographic and geochemical features similar to those of other topaz-bearing granites in Finland (Haapala 1977a, 1997, Rämö 1991, Edén 1991). Recent petrographic and melt inclusion studies from the Eurajoki topaz granite verify an essentially magmatic origin of the anomalous geochemistry; the postmagmatic reactions have only slightly modified the composition of the granite (Haapala 1997, Haapala \& Thomas 2000). Similar conclusions can be made about the geochemically anomalous topaz granites from the Artjärvi and Sääskjärvi stocks. Topaz as a magmatic accessory mineral indicates that the topaz granites from Artjärvi and Sääskjärvi have crystallized from F-rich melt (Lukkari \& Holtz 2000). The anomalous geochemical character of the granites has been further increased by postmagmatic fluid-rock reactions, including recrystallization and alteration of plagioclase to topaz, sericite and muscovite (see Haapala 1977a).

The fluid phase escaping from topaz granite, possibly mixed with heated meteoric water, has formed greisen veins in the granite and surrounding older rapakivi granites. Several of the greisen vein systems and greisen zones found in Finland 

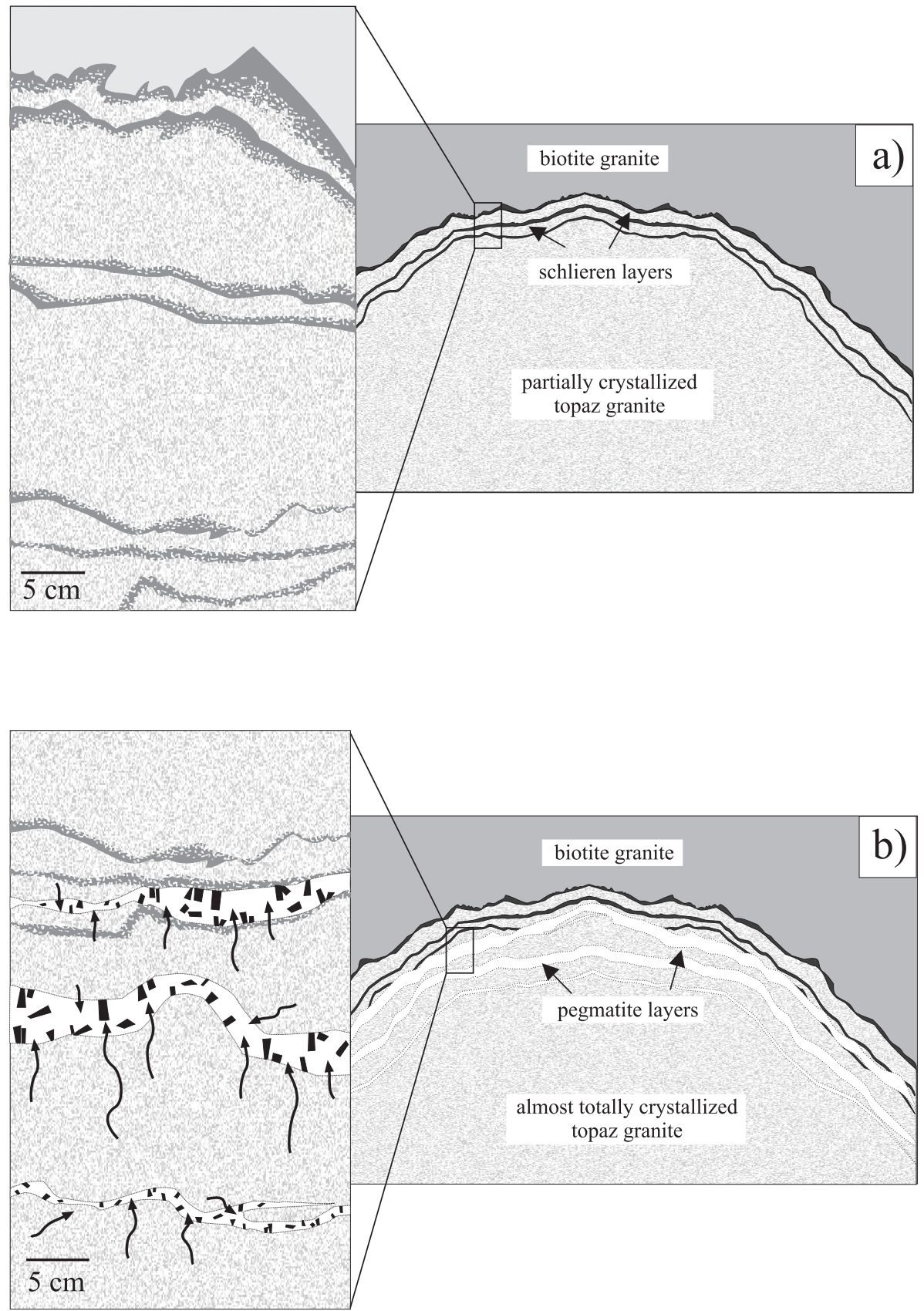

Fig. 11. A sketch showing a model of two-stage formation of the marginal layered pegmatite zones at Artjärvi. a) Formation of the schlieren layers under the roof of the magma chamber. The grading of the schlieren layers in proportions of mafic silicates is shown in the inset. In the two uppermost layers the amount of the mafic minerals decreases downwards from the upper contact, but the schlieren layers below have sharp bases and transitional upper parts. b) Formation of the pegmatite layers. Cooling and contraction of the topaz granite cupola resulted in formation of fractures parallel to the roof contact. Injection of residual pegmatite magma into these fractures formed pegmatite layers, which cut sharply both the schlieren layers and topaz granite. The arrows in the inset illustrate migration of the interstitial melt into the fractures. 
in association with topaz granites are tin-mineralized, but all are subeconomic (Haapala \& Ojanperä 1972, Haapala 1977a, 1977b, Edén 1991). Similarly, at Artjärvi and Sääskjärvi some of the greisen veins are mineralized with sulfide minerals, cassiterite, and columbite.

\section{Stockscheider}

The most characteristic feature of the Artjärvi granite stock is the marginal stockscheider at the roof contact of the topaz granite. The stockscheider has fine-scale layers consisting of alternating biotite-rich and biotite-poor layers, and several pegmatite layers parallel to the contact. Gravitational crystal settling (Kleck 1996), and oscillatory nucleation controlled by either diffusion (Webber et al. 1997), volatile-enriched boundary layers (Morgan \& London 1999) or volatile components $\left(\mathrm{H}_{2} \mathrm{O}, \mathrm{B}\right)$ (Rockhold et. al. 1987) have been proposed as possible mechanisms for the fine-scale rhythmic layering in layered pegmatiteaplite dikes. However, at Artjärvi the occurrence of oriented biotite crystals within the biotite-rich layers suggests that they are schlieren layers accumulated during magmatic flow rather than by crystallization in situ.

Several different mechanisms have been proposed for schlieren layering, including gravitational sorting, shear-flow sorting associated with melt escaping from a flowing crystal-rich magma (Weinberg et. al 2001), and velocity-gradient flow sorting (Tobish et. al 1997). At Artjärvi the uppermost schlieren layers show grading in the proportion of mafic minerals. The amount of the mafic minerals decreases downwards from the upper contact, so that gravitational crystal settling is the least probable mechanism for formation of schlieren layers. Weinberg et al. (2001) describe the origin of marginal schlieren by the combined effects of shear flow to concentrate crystals and the displacement of interstitial melt. At Artjärvi, the surrounding even-grained biotite granite shows no evidence for extraction of interstitial melt from the topaz granite mush. Therefore, the schlieren layers at Artjärvi are unlikely to have formed by this mechanism. Instead, the velocity-gradient flow sorting mechanism described by Tobish et al. (1997) may explain the schlieren layering at Artjärvi. Narrowing of a magma chamber produces an increase in flow velocity, which may cause mafic cumulates to accumulate underneath the overhang and along the walls. Most of the accumulation occurs with upward vertical flow, but accumulation also occurs under horizontal flow conditions (Tobish et al. 1997). At Artjärvi this mechanism may have accumulated the mafic minerals along the upper contact of the topaz granite forming the schlieren layering. The presence of biotite crystals oriented parallel to the schlieren layers indicates accumulation during subhorizontal flow along the hanging wall contact.

Layered pegmatite-aplite dikes have been described as being produced 1) by a single injection of magma, in which the compositional and textural zoning results from internal igneous processes (e.g. Burnham \& Nekvasil 1986, Webber et al. 1997, Morgan \& London 1999), 2) by multiple injections, in which each pulse segregates into a granite-pegmatite couplet (Rockhold et al. 1987), or 3) by injections of residual melt into not fully crystallized granite (Lynch \& Pride 1984, Breiter et al. 1997). At Artjärvi there is no evidence of periodic removal of fluxing components (e.g. B, F) that could have caused periodic crystallization of granitic and pegmatitic layers, nor is there any indication that the granite-pegmatite pairs represent separate, roughly coeval magma injections. It is suggested here that cooling and contraction after crystallization of the roof zone formed fractures parallel to the roof contact of the topaz granite cupola, and residual pegmatite magmas was injected into the fractures (Fig. 11). This interpretation is supported by the observation that the pegmatite layers show sharp contacts against the topaz granite and cut both topaz granite and schlieren layering (Fig. 3b). The whole rock chemical analyses show no vertical changes in composition of the granite and pegmatite layers in the stockscheider. The subhorizontal pegmatite layers indicate shallow depth emplacement into brittle country rock (Brisbin 1986).

Textures such as graphic intergrowths between quartz and feldspars, aplitic groundmass, and fan- 
shaped alkali feldspar crystals associated with the Artjärvi porphyritic biotite granite and pegmatite were probably generated by various degrees of undercooling. The miarolitic cavities found in the porphyritic biotite granite and topaz granite, however, indicate crystallization during volatile-saturated conditions (Haapala 1977a, Candela 1997)

ACKNOWLEDGEMENTS. I wish to thank Prof. Ilmari Haapala for initiating this study, and for his constructive comments on the early versions of this paper. I also express my thanks to Prof. Eric Christiansen and Prof. Don Burt for their valuable comments concerning the manuscript. Part of the chemical analyses was performed at the Geochemical Laboratory of the Depatrment of Geology, University of Helsinki; Antti Vuorinen and Tuija Vaahtojärvi are acknowledged for their assistance. Stephen Frindt is greatly acknowledged for valuable discussions and comments. This study was funded by the University's Research Funds (project 2105005, leader Prof. I. Haapala) and by the Foundation for Research of Natural Resources in Finland. Financial support from the Wilhelm Ramsay and Th. G. Sahama Memorial Foundation is also acknowledged. This paper is a contribution to IGCP Project 373 Correlation, Anatomy and Magmatic-Hydrothermal Evolution of OreBearing Felsic Igneous Systems in Eurasia.

\section{REFERENCES}

Boynton, W.V. 1984. Cosmochemistry of the rare earth elements: meteorite studies. In: Henderson P. (ed.) Rare Earth Element Geochemistry. Amsterdam: Elsevier, 63114.

Breiter, K., Frýda, J., Seltmann, R. \& Thomas, R. 1997. Mineralogical evidence of two magmatic stages in the evolution of an extremely fractionated P-rich rare-metal granite: the Podlesí stock, Krušné Hory, Czech Republic. Journal of Petrology 38, 1723-1739.

Brisbin, W.C. 1986. Mechanics of pegmatite intrusion. American Mineralogist 71, 644-651.

Burnham, C.W. \& Nekvasil, H. 1986. Equilibrium properties of granite pegmatite magmas. American Mineralogist 71, 239-263.

Candela, P.A. 1997. A review of shallow, ore-related granites: Textures, volatiles, and ore metals. Journal of Petrology 38, 1619-1633.

Edén, P. 1991. A specialized topaz-bearing rapakivi granite and associated mineralized greisen in the Ahvenisto complex, SE Finland. Bulletin of the Geological Society of Finland 63, 25-40.

El Bouseily, A.M. \& El Sokkary, A.A. 1975. The relation between $\mathrm{Rb}, \mathrm{Ba}$, and $\mathrm{Sr}$ in granitic rocks. Chemical Geology 16, 207-219.

Elliott, B. 1999. Colour masks in digital image analysis: a technique for modal analyses of quartz saturated plutonic rocks. Bulletin of the Geological Society of Finland 71, 233-241.

Haapala, I. 1977a. Petrography and geochemistry of the Eurajoki stock; a rapakivi-granite complex with greisen-type mineralization in southwestern Finland. Geological Survey of Finland, Bulletin 286. 128p.

Haapala, I. 1977b. The controls of tin and related mineralizations in the rapakivi-granite areas of south-eastern Fennoscandia. Geologiska Föreningens i Stockholm Förhandlingar 99, 130-142.

Haapala, I. 1988. Metallogeny of the Proterozoic rapakivi granites of Finland. In: Taylor, R.P. \& Strong, D.F. (eds.) Recent advances in the geology of granite-related deposits. Canadian Institute of Mining and Metallurgy, Special volume 39, 124-132.

Haapala, I. 1995. Metallogeny of the rapakivi granites. Mineralogy and Petrology 54, 149-160.

Haapala, I. 1997. Magmatic and postmagmatic processes in tin-mineralized granites: topaz-bearing leucogranite in the Eurajoki rapakivi granite stock, Finland. Journal of Petrology 38, 1645-1659.

Haapala, I. \& Ojanperä P. 1972. Genthelvite-bearing greisens in southern Finland. Geological Survey of Finland, Bulletin 259. 22 p.

Haapala I. \& Thomas, R. 2000. Melt inclusions in quartz and topaz of the topaz granite from Eurajoki, Finland. Journal of Czech Geological Society 45, 149-154.

Kleck, W. 1996. Crystal settling in pegmatite magma. Geological Association of Canada and Mineralogical Association of Canada, Abstracts with Programs 21, A-50.

Le Maitre, R.W., Bateman, P., Dudek, A., Keller, J., Lameyre, J., Le Bas, M.J., Sabine, P.A., Schmid, R., Sorensen, H., Streckeisen, A., Woolley, A.R. \& Zanettin, B. 1989. A Classification of Igneous Rocks and Glossary of Terms. Oxford: Blackwell. 193 p.

Lukkari, S. \& Holtz, F. 2000. Phase relations on F-enriched leucogranitic melts at $200 \mathrm{MPa}$ : An experimental investigation. In: Lukkari, S. \& Haapala, I. (eds.) Rapakivi Granites and Associated Mineralization. IGCP Project 373 Field Conference in southern Finland, July 3-7, 2000, Excursion Guide and Abstracts. Helsinki University Press, p. 45.

Lynch, G.V. \& Pride, C. 1984. Evolution of a high-silica magma chamber: the Pattison pluton, Nisling Range alaskites, Yukon. Canadian Journal of Earth Sciences 21, 407-414.

Miller, C.F. \& Mittlefehldt, D.W. 1982. Depletion of light rare-elements in felsic magmas. Geology 10, 129-133.

Morgan, G.B. VI \& London, D. 1999. Crystallization of the Little Three layered pegmatite-aplite dike, Ramona District, California. Contributions to Mineralogy and Petrology 136, 310-330. 
Pearce, J.A., Harris, N.B.W. \& Tindle, A.G. 1984. Trace element discrimination diagrams for the tectonic interpretation of granitic rocks. Journal of Petrology 25, 956983.

Rämö, O.T. 1991. Petrogenesis of the Proterozoic rapakivi granites and related basic rocks of southeastern Fennoscandia: $\mathrm{Nd}$ and $\mathrm{Pb}$ isotopic and general geochemical constraints. Geological Survey of Finland, Bulletin 355. $161 \mathrm{p}$.

Rockhold, J.R., Nabelek, P.I., \& Glascock, M.D. 1987. Origin of rhythmic layering in the Calamity Peak satellite pluton of the Harney Peak Granite, South Dakota: The role of boron. Geochimica et Cosmochimica Acta 51, 487-496.

Rollinson, H. 1993. Using Geochemical Data: Evaluation, Presentation, Interpretation. Harlow, UK: Longman. 352 p.

Tischendorf, G. 1977. Geochemical and petrographic characteristics of silicic magmatic rocks associated with rareelement mineralization. In: Stemprok, M. (ed.) Metallization Associated with Acid Magmatism 2, 41-96. Geological Survey of Prague.
Tobish, O.T., McNulty, B.A. \& Vernon, R.H. 1997. Microgranitoid enclave swarms in granitic plutons, central Sierra Nevada, California. Lithos 40, 321-339.

Wall, V.J., Clemens, J.D. \& Clarke, D.B. 1987. Models for granitoid evolution and source composition. Journal of Geology 95, 731-749.

Webber, K.L, Falster, A.U., Simmons, W.B. \& Foord, E.E. 1997. The role of diffusion-controlled oscillatory nucleation in the formation of line rock in pegmatite-aplite dikes. Journal of Petrology 38, 1777-1791.

Weinberg, R.F., Sial, A.N. \& Pessoa, R.R. 2001. Magma flow within the Tavares pluton, northeastern Brazil: compositional and thermal convection. Geological Society of America, Bulletin 113, 508-520.

Whalen, J.B., Currie, K.C. \& Chappell, B.W. 1987. A-type granites: geochemical characteristics, discrimination and petrogenesis. Contributions to Mineralogy and Petrology $95,407-419$. 